\title{
UPACARA NGUSABHA SATUH \\ DI PURA DALEM BANJAR PAKEL DESA GEGELANG
}

(Perspektif Agama dan Kebudayaan)

\author{
I Putu Sarjana \\ Fakultas Ilmu Agama dan Kebudayaan \\ sarjanaputu63@gmail.com
}

\begin{abstract}
ABSTRAK
Tulisan ini mengkaji tentang Ngusabha Satuh di Pura Pura Dalem Banjar Pakel Desa Gegelang Kecamatan Manggis Kabupaten Karangasem antara lain; daksina, peras, soda, banten pengambian, prayascita, byakawonan, penyeneng dan caru ayam berumbun. Materi utama dari upacara Ngusabha Satuh tersebut adalah satuh dan Emping. Upacara Ngusabha Satuh yang dilaksanakan di Pura Dalem Banjar Pakel mempunyai makna religius magis, makna kesucian dan makna pendidikan (pendidikan tattwa, pendidikan etika dan pendidikan upacara). Makna religius magis upacara Ngusabha Satuh sebagai suatu sradha/keyakinan bahwa upacara ini memiliki makna dan tujuan untuk memohon kesehatan atau keselamatan agar tidak diserang wabah penyakit (Gering) diwujudkan melalui upakara (banten). Kesucian jasmani dan rohani, sekala dan niskala yang diutamakan dalam upacara ini merupakan makna kesucian yang terkandung dalam upacara Ngusabha Satuh ini. Sebagai rasa angayu bagia kehadapan Ida Sang Hyang Widhi beserta Ista Dewatanya. Sebagai Sradha Bhakti atas anugrah yang dilimpahkan kepada manusia.
\end{abstract}

\section{PENDAHULUAN}

Diantara sejumlah pelaksanaan upacara yang dilakukan oleh masyarakat Hindu pada desa-desa di Bali dikenal adanya upacara Ngusabha. Kata Ngusabha sering dihubungkan dengan pelaksanaan Ngusabha Nini, Ngsabha Desa yang pada intinya adalah memohon kehadapan Ida Hyang Widhi agar masyarakat mendapatkan keselamatan. Pada desa-desa di Kabupaten Karangasem biasa dikenal Ngusabha yang agak berbeda dengan daerah lainnya di Bali seperti Ngusabha Dodol, Ngusabha Goreng, sedangkan di Desa Pakel Desa Gegelang ada sebuah upacara Ngusabha yang unik dilaksanakan di Pura Dalem yang disebut dengan Ngusabha Satuh.

Ngusabha Satuh dilaksanakan pada Sasih Jyesta tepatnya pada penanggal ping tiga (3). Sasih Jyesta menurut masyarakat di Banjar Pakel adalah sasih yang diyakini sebagai bulan yang mendatangkan wabah penyakit sehingga masyarakat perlu mengadakan persembahan berupa Ngusabha di Pura Dalem agar mendapat perlindungan dari Dewi Durga.

Karena keunikannya penelitian ini dilakukan dengan mengkaji secara teoritis bagaimanakan pelaksanaan upacara Ngusabha Satuh yang dilaksanakan oleh masyarakat Banjar 
Pakel Desa Gegelang Kecamatan Manggis Kabupaten Karangasem.

\section{PEMBAHASAN}

\subsection{Bentuk dan Pelaksanaan Upakara Ngusabha Satuh}

Menurut Ninian Smart (dalam Agung Paramita, 2018: 40) ada tujuh dimensi setiap agama. Salah satu dimensi yang penting adalah dimensi praktis-ritual. Upacara Ngusabha Satuh yang dilaksanakan oleh subak Banjar Pakel di Pura Bedugul di Desa Banjar Pakel Desa Gegelang Kecamatan Manggis Kabupaten Karangasem dilaksanakan setiap satu tahun sekali, selain untuk menjaga kelestarian ajaranajaran agama Hindu melalui upacara Ngusabha Satuh ini, anggota subak juga berharap dengan melaksanakan upacara Ngusabha Satuh ini panen mereka akan berasil dengan baik. Adapun bentuk dan jenis upakara yang dipergunakan dalam upacara Ngusabha Satuh oleh krama subak Banjar Pakel di Pura Dalem Desa Banjar Pakel Desa Gegelang Kecamatan Manggis Kabupaten Karangasem antara lain:

\section{Caru}

Caru ayam berumbun yaitu ayam bulunya berwarna merah, putih, kuning dan hitam. Setelah dipotong (bulunya tidak dicabuti) lalu dikuliti sedemikian rupa sehingga kepala, sayap, kaki dan ekor masih melekat satu sama lainnya. Dagingnya diolah digunakan 3 jenis uraban (urab barak, urab putih, gegecok) dan tiga jenis sate (sate lembat, sate asem, sate calon). Ketiga jenis uraban dan sate itu disebut Tri nayaka sebagai simbul jasmani ayam tersebut. setyelah semua dimasak lalu dibagi / ditanding menjadi beberapa bagian sebagai berikut; a. Sebuah klakat sudamala diisi daun telujungan, diisi nasi sabeh berumbun

b. Datengan, terbuat dari sebuah taledan dengan tangkih 8 buah dan masing-masing tangkih diisi nasi berumbun, dihulu taledan berisi dua ituk-ituk yang dilengkapi dengan raka-raka serta sampian plaus dan canang genten.

c. Bayuhan, taledan kecil berisi uraburaban dan sate dua jenis lembat dan asem) membuat 8 tanding.

d. Aled Bhulang, sebuah taledan dilengkapi ituk-ituk 8 buah di taruh mengelilingi taledan dan masingmasing ituk-ituk berisi porosan, bunga dan nasi berumbun, ditengahtengah taledan berisi nasi berumbun dengan pinda (bentuk) manusia, diatasnya dibentangkan kulit ayam tadi pada kepala ayam diisi sebuah kwangen diikat dengan karawista, kemudian disabeh dengan beras yang telah dicuci, disertai dengan base lembaran. Diatasnya lagi berisi segehan agung dan segehan warna 5 tanding ditambah 1 tanding segehan berumbun.

Banten-banten tersebut di atas dilengkapi dengan ketipat kelanan, daksina, pangulapan, pengambian, tulung, sasayut, peras, lis, sanga urip, penyeneng dan cau petik 8 buah berisi nasi berumbun, Banten-banten tersebut diatas dilengkapi dengan ketipat kelanan, daksina, pangulapan, prngambian, tulung, sasayut, peras, lis, sanga urip, penyeneng dan cau petik 8 buah berisi nasi berumbun, serta dilengkapi dengan kacang-kacang yang digandengkan. Disertai pula dengan 1 buah bungkak kelapa hijau dan sebuah padma, serta sengkui sebagai alasnya. 


\section{Byakawonan}

Memiliki fungsi sebagai penyomya (penetralisir) Bhuta Kala yang bersifat negatif (Sudarsana, 1998:48). Adapun tetandingannya sebagai berikut:

a. Alasanya sebuah sidi diatasnya berisi aled metajuh yang diisi kulit (seperti kulit peras terbuat dari daun pandan 5 buah)

b. Posisi luana; raka-raka meliputi tebu, pisang, jaja uli, dengan posisi jaja warna putih di kanan dan jaja barak dikiri, porosan, jaja gina, tape, bantal.

c. Diatas kulit itu berisi nasi kepelan, diatasnya ditancapkan bawang, tabia/cabe atau jahe, lengkap dengan kojong rangkadan (sambal, saur, kacang, gerang, timun, tuwung).

\section{Prayascita}

banten yang memiliki mutu kedewataan, oleh karena itu prayascita ini berfungsi untuk pembersihan dan merupakan simbul yang mengandung nilai religius sebagai kekuatan Siwa Guru (Sudarsana, 1998: 46). Prayascita juga bermakna menyucikan rohani secara sekala dan niskala (Sudarsana, 1998: 28). Adapun tetandingan prayascita sebagai berikut (Sudarsana, 1998: 86-87):

a. Tamas gede sebagai simbul windhu dan memiliki makna sebagai kekuatan Pawitra (penyucian).

b. 5 (lima) buah tulung sebagai simbul Panca Indriya memiliki makna sebagai permohonan kehadapan Sang Hyang Widhi agar Panca Indrianya dapat disucikan untuk menjadikan kekuatan Panca Dewata. c. 5 (lima) buah tipat kukur sebagai simbul angin, memiliki makna kekuatan penyucian.

d. 5 (lima) buah tumpeng menjadi simbul manca giri dan memiliki makna sebagai kekuatan Sang Hyang Panca Dewata.

e. Berisi nasi soda sebagai simbul Pradana Tattwa yang mengadung arti Sang Hyang Ayu dan memiliki makna memohon kerahayuan kehadapan Sang Hyang Siwa.

f. Sampian nagasari memiliki makna memohon sarining mertha.

g. Penyeneng memiliki makna memohon kehidupan kehadapan Sang Hyang Siwa.

h. Lis berasal dari kata les yang artinya inti dan memiliki makna inti permohonan adalah kesucian.

i. 5 (lima) buah kwangen adalah simbul ongkara waliang, memiliki makna sebagai kekuatan Sang Hyang Siwa Guru.

j. $\quad$ Berisi ceper diisi dengan tepung tawar, pengresikan dan pengelelenga sebagai simbol Tri Pramana memiliki makna sebagai kekuatan Sabda (tepung tawar), Bayu (pengresikan) dan Idep (pengelelenga).

k. Bungkak kelapa gading sebagai simbol toya (air) sukla memiliki makna sebagai kekuatan tirtha maha mertha (Siwa Tattwa).

1. Jajan, pisang, tebu, porosan memiliki makna seperti telah diterangkan didepan.

m. Kacang, saur dan sambal serta garam mengandung makna permohonan Sang Hyang Widhi agar dianugrahi 
kekuatan, keteguhan iman, kedamaian, kesidhian dan pengeleburan.

\section{Daksina}

Menurut Sudarsana dalam bukunya Ajaran Agama Hindu (1998: 25), kata daksina mengandung arti Brahma, dan Brahma menjadi Brahma yaitu Ida Sang Hyang Widhi. Daksina diringkai dari berbagai kemponen yang mengadung arti/ simbol:

a. Bedogan (tempatnya) dibuat dari daun janur yang agak tua/ daun rontal yang berbentuk silinder memiliki dua penampang atas bawah, dan penampang di bawah tertutup rapat sehingga menyerupai alas/ dasar, bentuk ini merupakan simbul bumi, cermin dari Sang Hyang Ibu Pertiwi.

b. Tampak Dara sebagai simbol suastika sumber pengatur seisi alam, cerminan dari adanya rwa bhinedha (adanya siang dan malam).

c. Beras simbolisasi dari udara sebagai cerminan Sang Hyang Bауи.

d. Pangi sebagai simbol sarwa phala bungkah, cermina Sang Hyang Boma.

e. Pelawa Peselan (daun-daunan), sebagai simbol tumbuhtumbuhan cerminan dari Sang Hyang Sangkara.

f. Biji-bijian yang dibungkus dengan daun kayu yang kering menjadi simbol biji-bijian alam semesta merupakan cerminan dari Jiwatman/roh. g. Tingkah sebagai simbol nadal Ardha Candra merupakan cerminan dari Paramasiwa.

h. Telor itik menjadi simbol bulan/ Ardha Candra merupakan cerminan Sang Hyang Siwa.

i. Kelapa simbol matahari / Windu merupakan cerminan Sang Hyang sadha Siwa.

j. Uang kepeng / Bolong (andelandel) simbol Windu Sunia merupakan cerminan dari Sang Hyang aji Akasa.

k. Benang putih sebagai simbol awan merupakan cerminan dari Sang Hyang Aji Akasa.

1. Porosan simbol silih asih merupakan cerminan dari Sang Hyang Semara Jaya, Samara Ratih.

m. Canang Sari menjadi simbol Sang Hyang Asta Aiswarya merupakan cerminan Dewata Nawa Sanga.

\section{Peras}

2007;28) menyebutkan peras merupakan perlambangan Sang Hyang Tri Guna Sakti. Kata peras dapat diartikan sah/ resmiSuatu upakara yang tidak dilengkapi dengan peras, upacaranya tan prasidal dapat dianggap tidak sah (Mas Putra, 1996;22). Adapun tatanan upakara peras sebagai berikut:

a. Sebagai alat banten ini disebut taledan berisi reringitan metampel pada taledan disebut kulit peras, berisi raka-raka antara lain: jaja uli, jaja begina merah dan putih, berisi porosan, daun pisang 
memakai kojong taledan tiga buah dalam tangkih sebagai tempat kacang, saur dan garam

b. Memakai sampian tetangga.

c. Memakai nasi tumpeng 2 (dua) buah.

Dari masing-masing upakara tersebut diatas mengandung simbol dan makna sebagai berikut:

a) Taledan berbentuk segi empat panjang sebagai simbol catur bala.

b) Kulit peras sebagai kekuatan Panca Maha Bhuta yang mengandung kekuatan dunia.

c) Sampian metetangga sebagai simbol alam fana dan alam baka adalah tunggal dilihat dari bentuknya bundar ndan besar. Penampangnya sama dengan aiswarya sekala niskala. Sampyan tetangga juga merupakan simbol cara berhubungan dengan dunia adalah melalui perputaran pelaksanaan catur yoga.

d) Kojong tabunan tiga buah berisi kacang, saur dan sambal merupakan simbol Tri kona, yaitu cerminan dari Tri Guna (satwam, rajas, tamas).

e) Jaja begina merah putih simbol permohonan kedamaian terhadap Sang Hyang Widhi yang bersifat purusa dan prakerti.

f) Jaja uli merah simbol permohonan terhadap Sang Hyang Widhi secara sekala niskala.

g) Tebu merupakan simbol amerta kehadapan Sang Hyang Widhi.

h) Buah-buahan simbol sebagai permohonan kehadapan Sang Hyang Widhi apa yang dipersembahkan sebagai umat agar dianugrahi sesuai dengan karmanya (pahala).

\section{Soda/Sodan}

Banten/ upkara sodan hampir sama tatanannya dengan upakara peras, bedanya pada bentuk nasinya yang berbentuk penek dengan sampyan uras, Nasi penek simbol danau/laut sebagai cermin kekuatan predana (prakerti) dari kekuatan Sang Hyang Widhi.

\section{Banten Pengambian}

Banten pengambian mirip dengan banten peras hanya berisi tipat pengambian.Kata pengambian terdiri dari suku kata ambe artinya tarik mendapat awalan $p a$ sisipan $n g$ dan akhiran an menjadi pengambian yang mengadung suatu pengertian untuk menarik kekuatan supra natural kekuatan Bhuana Agung ( alam semesta) dan kekuatan semua makhluk ( bayu pramana) agar menemukan kekuatan kembali dalam artian memohon kehadapan Sang Hyang Widhi Wasa agar dianugrahi kekuatan alam semesta khususnya kekuatan spiritual bagi orang yang beryadnya sebagai sumber kehidupan ( Sudarsana,1998;35). Adapun tandingannya sebagai berikut (Sudarsana, 1998:86-87):

a. Alasanya kekebat aled matajuh

b. Posisi luan (hulu) raka-raka meliputi; tebu, pisang, jaja uli, dengan posisi jaja warna putih dikanan dan jaja warna barak dikiri, jaja gina, tape, bantal.

c. Nasi tunpeng 2 (dua) dan kojong rangkadan dengan posisi sambal dikanan, kacang, saur,gerang,tuwung dikiri. 


\section{d. Ketipat pengambian I (satu)}

e. Tulung pengambian

f. Sampian pengambian dengan jumlah janur dasar 17 dan atas 17.

Mengenai penggunaan upakara tersebut dapat diuraikan sebagai berikut:

1). Untuk pelinggih taksu munggah ketipat kelanan dasina, peras, sodan, canang wangi.

2). Pelinggih Gedong yang merupakan pelinggih Bhatara Sri munggah ketipat daksina, peras, lis, penyeneng, sodan, canang wangi.

1) Di Bebaturan yang merupakan penghayatan Ida Bhatara di Ulun Sui munggah ketipat, daksina, peras, sodan.

2) Di pelinggih gedong yang merupakan penghayatan Ida Bhatara di Tanah Lot munggah banten tipat daksina, peras, lis, sodan.

3) Di natar jeroan menggunakan caru siap putih dengan reruntutan banten selengkapnya. Dibuat panggung/ asagan yang terletak ditengah natar utama mandala dengan upakara munggah adalah suci 2 soroh, sorohan 2 soroh, esayut tebasan, pengulapan, pengambian, biokaonan, sesayut pamerascita, penyeneng, (guling babi tingkat utama). Di Madyaning mandala mendirikan sanggah cukcuk munggah ketipat daksina, dibawah / ring sor caru siap brumbun dengan banten selengkapnya.

\section{Penyeneng}

Memiliki makna permohonan kehadapan Ida Sang Hyang Widhi agar dianugrahi kehidupan baik untuk bhuana agung maupun bhuana alit dalam keseimbangan dan keselarasannya (Sudarsana, 1998:41). Bentuk penyeneng, dasarnya ituk-ituk, isinya beras, porosan, jinah bolong I kepeng. Dalam penyeneng ada 3 (tiga) lekukan yang isinya tepung beras dan dadap berisi kapas, sisig/ jaja gina metunu. Di dalam ituk-ituk sebagai alas penyeneng berisi beras, porosan. Di atasnya benang putih sebagai simbol akasa/ Bayu.

Dari uraian diatas dapat diketaui upacara Ngusabha Satuh yang dilaksanakan oleh krama subak Banjar Pakel di Pura Dalem Desa Desa Gegelang Kecamatan Manggis Kabupaten Karangasem dilaksanakan secara khidmat dan meriah. Hal yang sama juga diungkapkan oleh Bendesa adat Banjar Pakel sepintas upakara yang digunakan serupa dengan upacara pengodalan, hal ini dikarenakan di Pura Dalem ini tidak pernah diadakan upacara pengodalan. Dapat peneliti katakan bahwa upacara Ngusabha Satuh yang dilaksanakan oleh krama subak Banjar Pakel akan berbeda dengan bentuk Ngusabha yang lainnya seperti Ngusabha Desa, Ngusabha Sambah dan lain sebagainya tetapi mengenai makna dan fungsinya adalah lebih ditujukan kepada memohon kehadapan Hyang Widhi agar terhindarkan dari segala mara bhaya (Gering).

\section{Pajegan Satuh.}

Banten Pajegan Satuh diletakkan di depan Linggihan Ratu Ida Bhatara Dalem, dengan susunan paling bawah mempergunakan pisang, buah-buahan, nasi piser, telor, kacang saur dan di atasnya tersunsun satuh dan emping.

Tetandingannya mengerucut ke atas di tengah-tengahnya dipasang 
sampian. Filosofi mengerucut ke atas adalah simbolis dari alam Bhur loka, Bwah loka dan Swahloka yakni dikhususkan pada saktinya Dewa Siwa yaitu Durga.

Persembahan ini diharapkan Dewi Durga bisa memberikan perlindungan kepada umat khususnya pada sasih Jyesta, menurut anggapan masyarakat di banjar Pakel sasih ini dianggap keramat, desti dianggap mengganggu kehidupan masyarakat untuk itu umat Hindu di Banjar Pakel melakukan permohonan kepada Ida Hyang Widhi dalam manifestasinya sebagai Dewi Durga.

\subsection{Tata Cara Pelaksanaan Upacara Ngusabha Satuh}

Pelaksanaan upacara Ngusabha Satuh dilaksanakan pada Penanggal ping tiga (3) sasih Jyesta. Upacara Ngusabha Satuh diikuti oleh Krama Banjar Pakel dan Banjar Babakan Desa Gegelang. Persiapan upacara biasanya dimulai sejak 6 hari sebelum pelaksanaan Ngusabha Satuh. Tahap persiapan upacara diawali dengan ngaturang ayah istri dan lanang, untuk membuat persiapan upacara yang akan dipakai dalam pelaksanaan upacara Ngusabha Satuh tersebut.

Proses pembuatan sarana upacara dilakukan secara bersama-sama sesama anggota subak dipimpin oleh seorang tapeni dari Banjar Babakan dan beberapa sarati yang ada di Banjar Pakel. Anggota masyarakat yang wanita (krama istri) mengerjakan segala keperluan pelaksanaan upacara sedangkan krama yang laki-laki (lanang) mempersiapkan sarana upacara seperti: Lapan (tempat sesaji), Ngulat klakat, mempersiapkan ulam caru, dan berbagai sarana yang menjadi kewajiban krama lanang. Setalah perangkat upacara selesai pada puncak upacara semua krama banjar Pakel dan Banjar Babakan mengikuti kegiatan Ngusabha dengan harapan apa yang dia lakukan semoga Ida Sanghyang Widhi selalu memberikan kemakmuran bagi anggota krama subak dan pelaksanaan upacara dipuput oleh seorang sulinggih Siwa Budha.

\subsection{Fungsi Upacara Ngusabha Satuh}

Upacara Ngusabha mempunyai fungsi yang sangat mendalam dalam hubungannya dengan kerukunan keselamatan serta kesuburan isi alam semesta untuk menjaga dan mengembalikan adanya keseimbangan antara bhuana alit dan bhuana agung dengan rasa syukur angayu bagia atas anugrah Ida Sang Hyang Widhi. Dalam persebahan dan pemujaan pada hakeketnya merupakan permohonan terhadap Brahma dalam Ista Dewatanya, Wisnu dan Pretiwi Dewi untuk kesehjatraan dan kebahagiaan umat manusia, agar bumi menjadi subur karena adanya hujan dan air sehingga tanaman seluruhnya berhasil dan akibatnya umat manusiapun menjadi sejahtra dan bahagia karena dapat menikmatinya. Dalam hidup dan kehidupan ini seperti yang dikemukakan dalam sloka Bhagawadgita, III: 14, sebagai berikut:

\section{Annād bavanti Bhūtān \\ Varjanyād anna-sambawah \\ Yadñād bhawanti tarjanyo \\ Yadñah karma-samudbhawah}

Artinya: hidup,

Karena makanan makhluk

\section{VIDYA WERTTA}

Vol. 1 Nomor 2, Oktober 2018 
Karena hujan makanan tumbuh,

Karena persembahan hujan turun,

Dan persembahan lahir karna kerja (Pendet, 1976:72).

Kalau di analisa dan dikaji secara mendalam jelas sekali memiliki titik temu dan keselarasan dengan pelaksanaan upacara Ngusabha selaku permohonan dan kebahagiaan umat manusia kehadapan Siwa dan Ista Dewatanya, Durga dan Pertiwi Dewi. Ngusabha yang dipersembahkan dengan tujuan agar masyarakat Banjar Pakel dan Banjar Babakan terhindarkan dari mala petaka (gering). Selain upaya yang dilakukan oleh umat Hindu di Banjar Babakan dan Banjar Pakel upacara Ngusabha juga memiliki fungsi :

1. Sebagai rasa angayu bagia kehadapan Ida Sang Hyang Widhi beserta Ista Dewatanya,

2. Sebagai sraddha Bhakti atas anugarah yang dilimpahkan kepada manusia, maka manusia sangatlah wajib membuat suatu pesta atau jamuan sebagai perwujudan Bhakti yang tulus iklhas kehadapan Sang Hyang Widhi. Dengan cinta kasihnya pula memberikan anugrah kepada seluruh krama, agar terhindar dari mara bahaya/kegeringan (fungsi religius magis).

3. Upacara Ngusabha berfungsi sebagai pendidikan agama Hindu. Pendidikan dalam kamus besar bahasa Indonesia (Depdikbud, 1990/ 2004) adalah proses pengubahan sikap dan tingkah laku seseorang melalui upaya orang dalam usaha mendewasakan manusia dengan pengajaran dan pelatihan dimana ada proses perbuatan, cara mendidik. Bertitik tolak dari pengertian ini, kajian jenis upakara Ngusabha secara esensial telah memberi warna terhadap tujuan yang ingin dicapai sehingga upacara Ngusabha ini tetap lestari dan tentunya fungsional bagi masyarakat baik dalam hal mendidik para generasi muda agar selalu bhakti dan menjaga keharmonisan sekala niskala dengan alam lingkungannya. Jadi fungsi pendidikan agama Hindu yang dimaksud adalah Tri Hita Karana. Tri Hita Karana adalah dijadikan konsep ajaran agama Hindu yang sangat mendalam tentang prinsip keseimbangan yaitu: keseimbangan antara manusia dengan Hyang Widhi (parahyangan), manusia dengan manusia (pawongan) dan kesemimbangan antara manusia dengan lingkungan (palemahan). Terkait dengan upakara Ngusabha sebagai fungsi pendidikan yang dimaksud yaitu penekanan difokuskan hubungan antara manusia dengan Sang Hyang Widhi beseta Ista Dewatnya yang menguasai Pura Dalem karena pelaksanaan upacara dilaksanakan di Pura Dalem. 
2.4 Nilai-nilai Pendidikan Agama Hindu Pada Upacara Ngusabha Satuh di Pura Dalem di Banjar Pakel Desa Gegelang

Berdasarkan uraian/paparan di atas maka upacara Ngusabha Satuh mempunyai unsur-unsur pendidikan di antaranya adalah nilai pendidikan religius magis, nilai pendidikan kesucian, nilai pendidikan tattwa, nilai pendidikan susila dan nilai pendidikan upacara.

\subsubsection{Nilai pendidikan Religius Magis}

Unsur pendidikan Religius Magis dari upacara Ngusabha Satuh sebagai suatu Sradhal keyakinan, bahwa dengan mengadakan upacara Ngusabha Satuh diyakini akan memiliki makna, tujuan dan pengaruh yang besar dalam usaha menjaga kestabilan alam yakni manusia berusaha dengan persembahan memohon keselamatan dan keberhasilan dalam menjaga keharmonian alam yang diwujudkan dengan upakaral banten. Diyakini dengan mengadakan upacara Ngusabha Satuh masyarakat Banjar Pakel akan terhindarkan dari bentuk segala bentuk dan gangguan penyakit. Upacara Ngusabha Satuh ini juga merupakan ungkapan rasa syukur mereka kehadapan Ida Sang Hyang Widhi dengan Ista Dewatanya yaitu Dewi Durga sebagai Dewa atas penguasa Gering dan penyakit dengan adanya permohonan terhadap beliau diharapkan (sarwa tinandur, sarwa tinurip) untuk bisa hidup dengan sabar sehingga dapat dinikmati oleh manusia dalam hidup dan kehidupan ini. Makna religius magis juga dapat dicermati dari banten seseorang akan merasa mantap hatinya memuja Hyang Widhi, apabila suatu persembahan (banten) kongkrit yang dihaturkan kepada beliau. Sarana banten juga merupakan perwujudan rasa terima kasih yang dilandasi oleh pandangan simbolik fisolofis yang dalam.

\subsubsection{Nilai Pendidikan Kesucian}

Tujuan kita melaksanakan upacara yadnya adalah mencapai kesempurnaan/ moksartam suka tan pawali duka. Guna memenuhi tujuan tersebut ajaran sastra mengatakan: orang tidak boleh berkata kasar dalam melaksanakan yadnya, orang tidak boleh berbuat jahat, tidak terpuji seperti mencuri, berhutang untuk melakukan yadnya, orang yang tidak boleh mencuri makanan dan minuman yang di suguhkan. Tidak berpikir pamrih dalam melaksanakan yadnya sebab yadnya adalah suguhan secara tulus ikhlas, hati bersih dan pikiran suci yang kita persembahkan kehadapan Ida Sang Hyang Widhi, karena kesucian Beliau yang telah menciptakan alam semesta ini dengan me- yadnya- kan diri-Nya. Keberhasilan suatu upacara dapat diukur dari kesucian upacara Ngusabha ini, kesucian bahan, kesucian pikiran, perkatan dan perbuatan dari krama subak sebagai yang melaksanakan upacara Ngusabha Satuh ini.Begitu juga kesucian dari peminpin upacara. Hal-hal yang prinsip dalam beryadnya antara lain: persembahan itu harus didasari oleh hati yang tulus ikhlas dan suci bersih, pikiran harus terpusat menuju kepada yang disembah. Adanya penggunaan banten prayascita dalam upacara Ngusabha Satuh ini juga sebagai gambaran bahwa dalam upacara Ngusabha Satuh terkandung makna kesucian dimana banten prayascita sendiri bermakna menyucikan rohani secara sekala maupun niskala. 


\subsubsection{Unsur Pendidikan Tattwa}

Unsur pendidikan tattwa yang menonjol dalam pelaksanaan upacara Ngusabha Satuh adalah terlihat dalam melaksanakan suatu upacara, masyarakat beragama Hindu di Bali, pelaksanaannya dalam pemujaan dan persembahannya, terutama bagi para bhakta dan karma margin tidak dapat dilaksanakan berdasarkan kemauan seseorang atau sekelompok orang saja. Tetapi pelaksanaannya harus selalu berpedoman pada odigium, desa, kala, patra dan desa mawacara serta negare nawa tata saja, dan juga pelaksanaannya selalu berpihak dan mempedomani Catur Dresta, terutama Sastra Dresta. Sehingga dengan demikian setiap pelaksanaan upacara di Banjar Pakel sejak dari awal dilakukan oleh Sang Yajamana sampi akhir pelaksanaan upacara.

Ngusabha Satuh memiliki makna tersendiri secara filosofis. Jadi makna pendidikan tattwa pada upacara Ngusabha Satuh adalah mendidik umat Hindu khususnya anggota masyarakat Barjar Pakel, terutama genarasi muda agar mampu untuk memahami dan melaksanakan upacara ngusabha Satuh secara berkesinambungan. Dari segi tattwa melalui persembahan dalam bentuk upacara diharapkan dalam pembuatan Upakaranya diharapkan selalu berpedoman dengan Sastra Dresta dan Catur Dresta.

Aktifitas masyarakat dalam mewujudkan sradha dan bhakti kehadapan Bhatari Durga dalam upacara Ngusabha Satuh memiliki makna filosofis tersendiri, hal ini adalah bentuk pengejawantahan dari nyasanyasa yang berdasarkan petunjuk dan konsep ajaran sastra agama. Disamping sebagai sadhana, juga sekaligus berfungsi sebagai obyek konsentrasi untuk mengimankan konsep-konsep filosofis tentang konsep ajaran tattwa juga tata susila dan upakara, termasuk eksistensi Hyang Widhi yang transendentil. Wujud banten sebagai nyasa dan sadhana itu tidak terlepas dari aspek filosofisnya.

Contohnya; sebodoh-bodohnya wanita Hindu di Bali yang ikut ngayah ke Pura pada waktu persiapan membuat banten, tentu dapat membuat unsur upakara

yang paling sederhana yang disebut porosan. Walaupun hanya sebuah porosan yang merupakan unsur upakara yang paling sederhana, yang mampu dikerjakan oleh hampir semua wanita Bali, tetapi ia telah memiliki konsep nyasa dan filosofis yang tinggi. Porosan sebagai salah satu unsur upakara adalah sebagai nyasa Tri Murti yang tak terlepaskan dari konsep ajaran filsafat ketuhanan.

\subsubsection{Unsur Pendidikan Susila}

Mendidik umat agar selalu menghormati, memuja aspek-aspek menifestasi dari Sang Hyang Widhi dalam pelaksanaan upacara Ngusabha melalui Ista Dewatanya, agar tercapai apa yang diharapkan. Mendidik umat untuk menjaga keharmonisan yang kita kenal dengan konsep Tri Hita Karana. Karena manusia adalah mahluk sosial yang tidak bisa hidup menyendiri selalu memerlukan bantuan orang lain, mempunyai keinginan untuk bergaul, hasrat untuk meniru atau beradaptasi.

Manusia mempunyai kemampuan disebut Tri Sakti yaitu Icha Sakti (kemampuan), Krya Sakti ( prana) dan Jnana Sakti (intelek), yang biasa disebut cipta, rasa dan karsa (bayu, sabda,idep). Kelebihan yang dimiliki 
ileh manusia dibandingkan dengan mahluk ciptaan Tuhan lainnya adalah bisa membedakan mana yang baik dan mana yang buruk dalam beretika dan ber- tat Twam Asi.

Etika atau susila bergerak dalam lapangan kesusilaan artinya bertalian dengan norma-norma yang harus ditaati. Ethika berkedudukan sebagai ilmu pengetauan tata susila yang mengatur tingkah laku manusia dalam hubungannya dengan Tuhan, dengan sesama dan dengan alam sekitarnya. Agar perbuatannya tidak menyimpang dari ajaran agama, maka etika merupakan bagian yang tidak terpisahkan dari ajaran agama Hindu yang mengatur dan menentukan tingkah laku manusia. Jadi etika berperan penting dalam theologi Hindu sehingga etika merupakan landasan dan pedoman umat manusia dalam mengurangi lautan hidup dan kehidupan di dunia ini untuk mendapatkan kesehjatraan dan kebahagiaan di dunia fana (Wiratmaja, 1995:23).

Kerangka dasar agama Hindu; Tattwa, Etika, dan Upacara merupakan cerminan dari Tri Angga Sarira dari manusia antara lain adanya badan Atma yang bermanifestasi sebagai mahat dan tercermin sebagai tattwa. Yang kedua adanya badan antakarana sarira (jiwa) bermanifestasi sebagai budhi dan tercermin menjadi etika (prilaku) dan ynag terakhir adanya jasad/ tubuh (Panca Maha Bhuta) yang bermanifestasi sebagai ahamkara yang tercermin menjadi upacara (bersifat material) (Sudarsana, 1998: 3). Etika dan upacara tanpa berdasarkan tattwa pelaksanaan tersebut dikatakan buta. Sedangkan suatu upacara yang ditunjang oleh tattwa tanpa etika pelaksanaan tersebut dikatakan tuli. Demikian juga sebaliknya suatu upacara yang hanya ditunjang oleh tattwa dan etika tanpa adanya upakara itu dinamakan lumpuh (Sudarsana, 1998: 12). Karena melaksanakan upacara harus terlebih dahulu diketaui tentang makna dan nama upacara (tattwa) lalu bagaimana jenis upakaranya. Etika dalam upacara dimulai dari pelaksanaan yasa kerthi.

\subsubsection{Nilai Pendidikan Upacara}

Mendidik masyarakat atau krama subak untuk dapat membuat upakara dapat mengetahui simbolsimbol dalam upakara yang dipergunakan dalam upacar Ngusabha Satuh khususnya di Pura Dalem, dan secara turun-temurun dan dari generasi ke generasi berikutnya pengetahuan tentang upacara Ngusabha Satuh dapat dipergunakan dan dilestarikan, guna keajegan subak sebagai salah satu warisan kebudayaan Bali.

\section{PENUTUP}

Dari uraian permasalahan permasalahan diatas, maka dapat ditarik kesipulan sebagai berikut:

1. Pelaksanaan dan upakara yang dipergunakan dalam upacara Ngusabha Satuh di Pura Pura Dalem Banjar Pakel Desa Gegelang Kecamatan Manggis Kabupaten Karangasem antara lain; daksina, peras, soda, banten pengambian, prayascita, byakawonan, penyeneng dan caru ayam berumbun. Materi utama dari upacara Ngusabha Satuh tersebut adalah satuh dan Emping.

2. Upacara Ngusabha Satuh yang dilaksanakan di Pura Dalem Banjar Pakel mempunyai makna religius magis, makna kesucian dan makna pendidikan (pendidikan

\section{VIDYA WERTTA}

Vol. 1 Nomor 2, Oktober 2018 
tattwa, pendidikan etika dan pendidikan upacara). Makna religius magis upacara Ngusabha Satuh sebagai suatu sradha/keyakinan bahwa upacara ini memiliki makna dan tujuan untuk memohon kesehatan atau keselamatan agar tidak diserang wabah penyakit (Gering) diwujudkan melalui upakara (banten). Kesucian jasmani dan rohani, sekala dan niskala yang diutamakan dalam upacara ini merupakan makna kesucian yang terkandung dalam upacara Ngusabha Satuh ini. Sebagai rasa angayu bagia kehadapan Ida Sang Hyang Widhi beserta Ista Dewatanya. Sebagai Sradha Bhakti atas anugrah yang dilimpahkan kepada manusia.

3. Nilai-nilai pendidikan yang terdapat dalam Upacara Ngusabha Satuh adalah Nilai pendidikan tattwa dari upacara Ngusabha Satuh adalah mendidik umat untuk memahami, menghayati serta bahwa sesungguhnya penyebab utama terjadinya semua di dunia adalah Hyang Widhi maka masyarakat di Banjar pakel diingatkan untuk melaksanakan upacara agar selalu ingat pada beliau, yang maha penyebab di dunia ini, Nilai pendidikan etika mengandung pendidikan kepada masyarakat Banjar Pakel hendaknya mengutamakan ketulusan, keheningan dan kesucian pikiran dalam membuat sarana yadnya, makna pendidikan upakara diajarkan pada masyarakat untuk bisa membuat banten suatu simbol/nyasa dalam Upacara Ngusabha Satuh juga berfungsi mendidik para generasi muda agar selalu Bhakti dan menjaga keharmonisan sekala niskala yang dapat kita lakukan melalui konsep Tri Hita Karana

\section{DAFTAR PUSTAKA}

Agung Paramita, 2018. Bencana, Agama dan Kearifan Lokal. (Jurnal Dharmasmrti Vol. 1 No. 18, Denpasar Jurnal Ilmu Agama dan Kebudayaan Universitas Hindu Indonesia, 2018).

Arikunto, Suharsini. 2002. Prosedur Penelitian Suatu Pendekatan Praktek, Jakarta : Rineka Cipta.

Arya, I Made. 2007. Skirpsi: Bentuk Fungsi Dan Makna Banten Pengraksa Karya

Di Desa Antapan kec. Selemadeg Barat Kab. Tabanan. UNHI: 2007

Direktorat Jenderal Pembangunan Masyarakat Desa. 2004. Profil Desa/ Kelurahan Buku III.

Gorda, I Gst. Ngurah. 1997. Metodelogi Penelitian Ilmu Sosial Ekonomi.

Denpasar: Widya Kriya Gunatama

Gulo.W.. 2002. Metodelogi Penelitian. Jakarta: PT. Gramedia Widya Sarana Indonesia

Hadi, Sutrisno.2002. Metodologi Research. Yogyakarta: Andi

Hasan, Iqbal.2002. Metodelogi dan Aplikasinya. Jakarta: Ghalia Indonesia

Kepala Dinas Kebudayaan Propinsi Daerah Tingkat I Bali. 1998. Sri Purana

Tattwa dan Petunjuk Prajuru Subak Di Bali.

Mardalis. 2004. Metode Penelitian Suatu Pendekatan Proposal. Jakarta: Bumi Aksara.

Mas, IGA. Md. Putra. 1998. Panca Yajna. Surabaya: Paramita 
Ngurah, I Gusti Agung.2005. Manajemen Penulis Skripsi, Tesis dan Desertasi. Jakarta: PT. Raja Grapindo Persada.

Ngurah, I Gusti Made.1999. Buku Pendidikan Agama Hindu Untuk Perguruan Tinggi. Surabaya: Paramita

Oka, Ngurah Supartha. 1990/2000.

Upacara Ngusabha Desa. Pemerintah Daerah Tingkat I Bali.: Proyek Peningkatan Sarana dan Prasarana Kehidupan Beragama.

Parisadha Hindu Dharma. 1995. Panca Yadnya; Dewa Yadnya, Bhuta Yadnya, Rsi Yadnya, Pitra Yadnya dan manusia Yadnya. Denpasar.

Pendet, I Nyoman S. 1976. Bhagawadgita. Denpasar: Lembaga Penyelenggara Penterjemah dan Penerbit Dharma Naradha.

Purwita, Ida Bagus Putu. 1978. Dewa Yajnya. Denpasar: Proyek Penyuluhan Agama dan Penerbitan Buku/ Brosur Keagamaan.

Putra, Ny. IGA.Mas. 1979. Upakara Yadnya.Kabupaten Badung: Dinas Agama Hindu dan Budha.

Redana, I Made. 2006. Panduan Praktis Penulisan Karya Ilmiah dan Proposal Research. Denpasar: IHDN. 